\title{
Generation of human B-cell lines dependent on CD40-ligation and interleukin-4
}

\author{
Jacques Banchereau ${ }^{1,2 *}$ \\ 1 Jackson Laboratory for Genomic Medicine, Farmington, CT, USA \\ 2 Vaccine Research Institute, U955, Hopital Henri Mondor, Creteil, France \\ *Correspondence: jacques.banchereau@jax.org \\ Edited by: \\ Kendall Arthur Smith, Weill Medical College of Cornell University, USA \\ Reviewed by: \\ Michael R. Gold, The University of British Columbia, Canada \\ Edward A. Clark, University of California Los Angeles, USA
}

Keywords: human B lymphocytes, isotype switch, plasma cells, memory B-cells, IL-4

\section{WHERE WE STARTED}

The description of factor-dependent cytotoxic T-cell lines in the late 1970s transformed T-cell biology (1). Among other events, it led to the cloning of a cDNA encoding IL-2 (2). It also led to the identification of T-cell subsets and formulation of the Th1/Th2 concept in the $80 \mathrm{~s}$ (3). However, comparable advances in B-cell biology were lacking, partly because of the lack of availability of factor-dependent Bcell lines. This was the case despite the fact that B-cell-specific trophic factors, including BSF (B-cell stimulation Factor), BCGF (B-cell growth factor), and BCDF (B-cell differentiation factor) had been described in the supernatants of activated T cells.

The cloning at DNAX, our sister institute acquired by Schering-Plough, of a cDNA encoding BSF-1, later renamed IL4 , in mouse (4) and in human (5) was a first step forward to the definition of the molecules controlling B-cell growth and differentiation. In our laboratory, based in Dardilly near Lyon (France), we found that cultured purified human B-cells triggered with anti-B-cell receptor (BCR) and IL-4 resulted in significant B-cell proliferation as measured by tritiated thymidine counts, a common way of measuring Bcell proliferation in the 1980-1990s (6). These cultures yielded more B-cells than did naïve cultures or those exposed to antiBCR alone or IL-4 alone. Yet, these cultures established with anti-BCR plus IL-4 yielded less viable B-cells than were input. Thus, we, B-cell biologists had not yet been able to reproduce with B-cells the factor-dependent growth of $\mathrm{T}$ cells that our colleagues T-cell biologists have been able to achieve.

\section{FEEDER CELLS AND NEW MONOCLONAL ANTIBODIES YIELD MORE ROBUST B-CELL CULTURES}

A possible explanation for our lack of success was the absence of feeder cells, which had become part of the T-cell culture system and proved necessary to allow for the expansion of human T-cell lines and clones. Meanwhile, Kevin Moore and his colleagues at DNAX, cloned a human cDNA coding for Fc $\gamma$ RII/CD32 and found that Fc $\gamma$ RII/CD32-transfected fibroblast cell lines could present monoclonal antibodies in a manner that allowed for cross-linking of the target molecule of the relevant cell $(7,8)$. More specifically, antibodies to the T-cell CD3 complex presented by these transfected cells together with IL-2 could induce prolonged T-cell proliferation (9). Thus, we wondered whether the presentation of monoclonal antibodies specifically directed at B-cell surface molecules in the presence of B-cell tropic cytokines would lead to the proliferation and expansion of Bcells.

By the end of the 80s, we, investigators from Schering-Plough/DNAX had cloned cDNAs encoding human GM-CSF (10), IL-4, IL-5 (5, 6), and FcgR/CD32 (8). We had also generated a number of monoclonal antibodies that would recognize Bcells including a CD40 antibody (11) and an anti-B7 antibody now known as CD86 (12). When Paolo de Paoli came to our lab to perfect his flow cytometry skills, he took a side project to refine methods for culturing sorted B-cells using both classical and new approaches, including the addition of a feeder-layer of CD32/Fc $\gamma$ R-transfected cells as discussed above (9).
To this end, 96-well-plate microwells were first seeded with the irradiated fibroblast line. A few thousand B-cells were then added along with a few selected monoclonal antibodies with or without IL-2 or IL-4. Cultures were harvested 3-5 days later after a brief pulse with tritiated thymidine. It very quickly became apparent that the combination of the CD40 antibody Mab 89 (11) and IL-4 could induce unusually strong B-cell proliferation. The wellknown CD40 antibody G28-5 made by Ed Clark and Jeff Ledbetter also proved highly effective in this system $(13,14)$. Curiously, IL-2 was unable to enhance CD40induced B-cell proliferation, although it did enhance the proliferation of B-cells activated through their BCR. Furthermore, the fibroblast layer provided some feeder effect, as cross-linking the CD40 antibody on plastic was never as effective in inducing prolonged B-cell proliferation as presenting it with the CD32-transfected fibroblast.

\section{NEW SYSTEM INCREASED B-CELL PROLIFERATION AND ENABLED LONG-TERM B-CELL CULTURE AND} STUDIES OF B-CELL DIFFERENTIATION

The next critical experiment was to determine whether these culture conditions actually increased the output of B-cells. Indeed, it was very rewarding to find that the cultures made with CD40 antibody and IL-4 did generate more B-cells than were initially seeded. Subsequent experiments showed that with this new method we could establish proliferative B-cell cultures using relatively low numbers of B-cells $(5,000$ or less per well) compared to our previous purified B-cell cultures triggered with anti-BCR $(20,000-50,000$ per well). This 
important finding, however, was not the end of the story, as we still had to show that this novel B-cell culture system would allow for the long-term growth (i.e., at least 3 weeks), of B-cells following splitting and feeding.

Some human B-cells harbor the Epstein-Barr virus (EBV), which, upon reactivation, can induce the generation of factor-independent lymphoblastoid B-cell lines. Thankfully, removal of the CD40 antibody and IL-4 quickly resulted in B-cell death. Furthermore, the factor-dependent B-cell lines failed to express EBNA-2 (Epstein-Barr Nuclear Antigen 2). These two findings led us to conclude that we were indeed generating factor-dependent human B-cell lines (15).

As is so often the case, novel methodologies enable us to address a whole new set of questions. We were thus wondering whether this new, feeder-layer/monoclonal antibody-based culture system would permit us to mimic many of the events happening in the germinal center where isotype switch, somatic mutations and differentiation into either memory B-cells or plasma cells are thought to occur (16). Indeed, Yong-Jun Liu and Ian McLennan showed that CD40-ligation prevents the spontaneous apoptosis of human centrocytes, which undergo antigen-driven selection within germinal centers (17). Our later studies and those from others demonstrated that CD40-activated B-cells could undergo isotype switch toward IgE when exposed to IL-4 or IL-13 $(18,19)$. Upon exposure to IL-10, CD40-activated B-cells switch toward IgG1 and IgG3 as well as IgA1 and IgA2 (20). The combination of IL-10 and TGF $\beta$ further enhances the IgA2 response. The critical studies led with the CD40 antibodies led to the cloning of it ligand (CD40-L), a molecule transiently expressed on $\mathrm{T}$ cells, by investigators at Immunex (21). The importance of CD40CD40-L interactions in isotype switching in humans was further established when patients devoid of functional CD40-L were shown not to display switched isotypes (22-25). In further studies using CD40L-transfected fibroblasts, rather than the combination of $\mathrm{CD} 32 / \mathrm{Fc} \gamma \mathrm{R}$-transfected fibroblasts and CD40 antibody, we could show that CD40-ligation induces germinal center B-cells to differentiate into memory $\mathrm{B}$-cells rather than plasma cells (26). Thus, this new culture method could robustly recapitulate key features of the germinal center and thus enable greater insight into the events leading to B-cell differentiation than previous approaches.

\section{EXPLOITING THE NEW B-CULTURE SYSTEM FOR GENERATING HUMAN MONOCLONAL ANTIBODIES}

A practical application of the CD40-system has been the efficient generation of human monoclonal antibodies. We eventually simplified the system to the point where peripheral blood cells (about 5,000 per well) from individuals displaying selected antibody specificities in their serum were simply cultured over CD40-L-expressing fibroblasts in the presence of exogenous EBV. Analysis of culture supernatants after 10 days eventually revealed the presence of antibodies of the desired specificity. This allowed us to generate large a number of monoclonal antibodies, such as those against the Bullous Pemphigoid Antigen1 (27), and against allergens, such as those from birch pollen (28). Nearly all these lines proved to be easy to generate; however, one set of autoantibodies gave us a hard time: autoantibodies against IL $1 \alpha$, which we previously found were expressed in about $10 \%$ of the healthy population. We generated dozens of B-cell lines producing anti-IL $1 \alpha$ antibodies but had difficulty cloning them. We eventually isolated a single clone (29) that produced a high affinity $\left(\mathrm{Kd} \sim 10^{-10}\right)$ neutralizing monoclonal antibody. The reason why the cloning of the lines generating these monoclonal antibodies suggested to us that IL $1 \alpha$ might have a critical role in B-cell expansion, an hypothesis we could not confirm. A strategic decision by the Schering-Plough leadership resulted in the discontinuation of our human monoclonal antibody program in 1994 around the time that the FDA rejected approval of the anti-sepsis monoclonal antibody, Nebacumab, also known as Centoxin ${ }^{\circledR}(30)$. Today, however, human monoclonal antibodies are a major success in the biotechnology and pharmaceutical world. Several methodologies to generate monoclonal antibodies are currently in use. These include: (1) engineering of mouse monoclonal antibodies, (2) generating monoclonal antibodies from animals whose Ig locus has been swapped with a human Ig locus, (3) the use of phage display libraries from pools of memory Bcells, (4) a method similar to ours where CD40-L cells were replaced by CpG (31), and (5) the isolation of single B-cells and the cloning of their heavy and light chains (32). Other have taken advantage of the power of the "CD40-system" to generate long-term B-cell lines that could be used as highly efficient antigen-presenting cells to generate autologous antigen-specific $\mathrm{T}$ cells for adoptive immunotherapy (33). The system can even permit the establishment of long-term porcine B-cell cultures (34). It is important to know that CD40 is expressed by a number of cell types other than B-cells. Most importantly dendritic cells express CD40 and are activated upon CD40-ligation (35). A few other cell types do as well [see Ref. (36)].

In conclusion, this study showed that it was possible to grow B-cells like $\mathrm{T}$ cells and opened up a path toward obtaining human monoclonal antibodies and understanding B-cell signaling. Before this work, many labs had tried to get human monoclonal antibodies from EBV transferred cells but the yields were small and most often low affinity IgM were generated. I am indebted in the numerous students and colleagues from Schering-Plough and DNAX who worked with me on these various projects. The support of Schering-Plough was essential for these studies.

\section{REFERENCES}

1. Gillis S, Baker PE, Ruscetti FW, Smith KA. Longterm culture of human antigen-specific cytotoxic T-cell lines. J Exp Med (1978) 148(4):1093-8. doi:10.1084/jem.148.4.1093

2. Kashima N, Nishi-Takaoka C, Fujita T, Taki S, Yamada G, Hamuro J, et al. Unique structure of murine interleukin-2 as deduced from cloned cDNAs. Nature (1985) 313(6001):402-4. doi:10. 1038/313402a0

3. Mosmann TR, Coffman RL. Two types of mouse helper T-cell clone implications for immune regulation. Immunol Today (1987) 8(7-8):223-7. doi: 10.1016/0167-5699(87)90171-X

4. Lee F, Yokota T, Otsuka T, Meyerson P, Villaret $\mathrm{D}$, Coffman $\mathrm{R}$, et al. Isolation and characterization of a mouse interleukin cDNA clone that expresses B-cell stimulatory factor 1 activities and T-cell- and mast-cell-stimulating activities. Proc Natl Acad Sci USA (1986) 83(7):2061-5. doi:10. 1073/pnas.83.7.2061

5. Yokota T, Otsuka T, Mosmann T, Banchereau J, DeFrance T, Blanchard D, et al. Isolation and characterization of a human interleukin cDNA clone, homologous to mouse B-cell stimulatory factor 1, that expresses B-cell- and T-cell-stimulating activities. Proc Natl Acad Sci USA (1986) 83(16):5894-8. doi:10.1073/pnas.83.16.5894 
6. Yokota T, Lee F, Rennick D, Hall C, Arai N, Mosmann $\mathrm{T}$, et al. Isolation and characterization of a mouse cDNA clone that expresses mast-cell growth-factor activity in monkey cells. Proc Natl Acad Sci USA (1984) 81(4):1070-4. doi:10.1073/ pnas.81.4.1070

7. Lewis VA, Koch T, Plutner H, Mellman I. A complementary DNA clone for a macrophage-lymphocyte Fc receptor. Nature (1986) 324(6095):372-5. doi: $10.1038 / 324372 \mathrm{a} 0$

8. Stuart SG, Trounstine ML, Vaux DJ, Koch T, Martens CL, Mellman I, et al. Isolation and expression of cDNA clones encoding a human receptor for IgG (Fc gamma RII). J Exp Med (1987) 166(6):1668-84. doi:10.1084/jem.166.6.1668

9. Peltz GA, Trounstine ML, Moore KW. Cloned and expressed human $\mathrm{Fc}$ receptor for IgG mediates anti-CD3-dependent lymphoproliferation. J Immunol (1988) 141(6):1891-6.

10. Lee F, Yokota T, Otsuka T, Gemmell L, Larson $\mathrm{N}$, Luh J, et al. Isolation of cDNA for a human granulocyte-macrophage colony-stimulating factor by functional expression in mammalian cells. Proc Natl Acad Sci USA (1985) 82(13):4360-4. doi:10.1073/pnas.82.13.4360

11. Valle A, Zuber CE, Defrance T, Djossou O, De Rie M, Banchereau J. Activation of human B lymphocytes through CD40 and interleukin 4. Eur J Immunol (1989) 19(8):1463-7. doi:10.1002/eji. 1830190818

12. Valle A, Garrone P, Yssel H, Bonnefoy JY, Freedman AS, Freeman G, et al. mAb 104, a new monoclonal antibody, recognizes the B7 antigen that is expressed on activated B cells and HTLV-1-transformed T cells. Immunology (1990) 69(4):531-5.

13. Clark EA, Ledbetter JA. Activation of human B cells mediated through two distinct cell surface differentiation antigens, Bp35 and Bp50. Proc Natl Acad Sci USA (1986) 83(12):4494-8. doi:10.1073/pnas. 83.12.4494

14. Ledbetter JA, Shu G, Gallagher M, Clark EA. Augmentation of normal and malignant $\mathrm{B}$ cell proliferation by monoclonal antibody to the B cellspecific antigen BP50 (CDW40). J Immunol (1987) 138(3):788-94.

15. Banchereau J, de Paoli P, Vallé A, Garcia E, Rousset F. Long-term human B cell lines dependent on interleukin-4 and antibody to CD40. Science (1991) 251(4989):70-2. doi:10.1126/science. 1702555

16. MacLennan IC, Gray D. Antigen-driven selection of virgin and memory B cells. Immunol Rev (1986) 91:61-85. doi:10.1111/j.1600-065X.1986. tb01484.x

17. Liu YJ, Joshua DE, Williams GT, Smith CA, Gordon J, MacLennan IC. Mechanism of antigen-driven selection in germinal centres. Nature (1989) 342(6252):929-31. doi:10.1038/342929a0
18. Vercelli D, Jabara HH, Lauener RP, Geha RS. IL-4 inhibits the synthesis of IFN-gamma and induces the synthesis of IgE in human mixed lymphocyte cultures. J Immunol (1990) 144(2):570-3.

19. Rousset F, Garcia E, Banchereau J. Cytokineinduced proliferation and immunoglobulin production of human B lymphocytes triggered through their CD40 antigen. J Exp Med (1991) 173(3):705-10. doi:10.1084/jem.173.3.705

20. Defrance T, Vanbervliet B, Briere F, Durand I, Rousset F, Banchereau J. Interleukin 10 and transforming growth factor beta cooperate to induce anti-CD40-activated naive human B cells to secrete immunoglobulin A. J Exp Med (1992) 175(3):671-82. doi:10.1084/jem.175.3.671

21. Armitage RJ, Fanslow WC, Strockbine L, Sato TA, Clifford KN, Macduff BM, et al. Molecular and biological characterization of a murine ligand for CD40. Nature (1992) 357(6373):80-2. doi:10.1038/357080a0

22. Aruffo A, Farrington M, Hollenbaugh D, Li X Milatovich A, Nonoyama S, et al. The CD40 ligand, gp39, is defective in activated $\mathrm{T}$ cells from patients with X-linked hyper-IgM syndrome. Cell (1993) 72(2):291-300. doi:10.1016/0092-8674(93) 90668-G

23. Korthauer U, Graf D, Mages HW, Briere F, Padayachee M, Malcolm S, et al. Defective expression of T-cell CD40 ligand causes X-linked immunodeficiency with hyper-IgM. Nature (1993) 361(6412):539-41. doi:10.1038/361539a0

24. DiSanto JP, Bonnefoy JY, Gauchat JF, Fischer A, de Saint Basile G. CD40 ligand mutations in x-linked immunodeficiency with hyper-IgM. Nature (1993) 361(6412):541-3. doi:10.1038/361541a0

25. Allen RC, Armitage RJ, Conley ME, Rosenblatt $\mathrm{H}$, Jenkins NA, Copeland NG, et al. CD40 ligand gene defects responsible for X-linked hyperIgM syndrome. Science (1993) 259(5097):990-3. doi:10.1126/science.7679801

26. Arpin C, Dechanet J, Van Kooten C, Merville P, Grouard G, Briere F, et al. Generation of memory B cells and plasma cells in vitro. Science (1995) 268(5211):720-2. doi:10.1126/science. 7537388

27. Peyron E, Nicolas JF, Reano A, Roche P, Thivolet J, Haftek M, et al. Human monoclonal autoantibodies specific for the bullous pemphigoid antigen 1 (BPAg 1). J Immunol (1994) 153(3):1333-9.

28. Visco V, Dolecek C, Denepoux S, Le Mao J, Guret C, Rousset F, et al. Human IgG monoclonal antibodies that modulate the binding of specific IgE to birch pollen Bet v 1. J Immunol (1996) 157(2):956-62.

29. Garrone P, Djossou O, Fossiez F, Reyes J, AitYahia S, Maat C, et al. Generation and characterization of a human monoclonal autoantibody that acts as a high affinity interleukin-1 alpha specific inhibitor.
Mol Immunol (1996) 33(7-8):649-58. doi:10.1016/0161-5890(96)00017-X

30. Marks L. The birth pangs of monoclonal antibody therapeutics: the failure and legacy of Centoxin. MAbs (2012) 4(3):403-12. doi:10.4161/ mabs. 19909

31. Traggiai E, Becker S, Subbarao K, Kolesnikova L, Uematsu Y, Gismondo MR, et al. An efficient method to make human monoclonal antibodies from memory B cells: potent neutralization of SARS coronavirus. Nat Med (2004) 10(8):871-5. doi: $10.1038 / \mathrm{nm} 1080$

32. Tiller T, Meffre E, Yurasov S, Tsuiji M, Nussenzweig MC, Wardemann H. Efficient generation of monoclonal antibodies from single human B cells by single cell RT-PCR and expression vector cloning. J Immunol Methods (2008) 329(12):112-24. doi:10.1016/j.jim.2007.09.017

33. Schultze JL, Seamon MJ, Michalak S, Gribben JG, Nadler LM. Autologous tumor infiltrating $\mathrm{T}$ cells cytotoxic for follicular lymphoma cells can be expanded in vitro. Blood (1997) 89(10):3806-16.

34. Takamatsu H, Andersen JK, Denyer MS, Parkhouse RM. Establishment of long-term CD154dependent porcine B-cell cultures. Immunology (1999) 97(2):211-8. doi:10.1046/j.1365-2567. 1999.00770.x

35. Caux C, Massacrier C, Vanbervliet B, Dubois B, Van Kooten C, Durand I, et al. Activation of human dendritic cells through CD40 cross-linking. J Exp Med (1994) 180(4):1263-72. doi:10.1084/jem.180. 4.1263

36. van Kooten C, Banchereau J. CD40-CD40 ligand. J Leukoc Biol (2000) 67(1):2-17.

Conflict of Interest Statement: The author declares that the research was conducted in the absence of any commercial or financial relationships that could be construed as a potential conflict of interest.

Received: 01 December 2014; accepted: 28 January 2015; published online: 11 February 2015.

Citation: Banchereau J (2015) Generation of human Bcell lines dependent on CD40-ligation and interleukin-4. Front. Immunol. 6:55. doi: 10.3389/fimmu.2015.00055 This article was submitted to B Cell Biology, a section of the journal Frontiers in Immunology.

Copyright (C) 2015 Banchereau. This is an open-access article distributed under the terms of the Creative Commons Attribution License (CC BY). The use, distribution or reproduction in other forums is permitted, provided the original author(s) or licensor are credited and that the original publication in this journal is cited, in accordance with accepted academic practice. No use, distribution or reproduction is permitted which does not comply with these terms. 